\title{
HUBUNGAN MOTIVASI DENGAN HASIL PEMBELAJARAN SEJARAH PADA SISWA KELAS X SMA NEGERI 8 PONTIANAK
}

\author{
Sahid Hidayat ${ }^{1}$, Agus Dediansyah $^{2}$ \\ ${ }^{1,2}$ Program Studi Pendidikan Sejarah \\ Fakultas Ilmu Pendidikan dan Pengetahuan Sosial IKIP PGRI Pontianak \\ Jalan Ampera Nomor 88 Pontianak - 78116, Telepon (0561) 748219 Fax. (0561) 589855 \\ ${ }^{1}$ Alamat e-mail: kelyk.hidayat@gmail.com
}

\begin{abstract}
Abstrak
Penelitian ini bertujuan untuk mengetahui hubungan motivasi dengan hasil belajar mata pelajaran sejarah pada siswa kelas X SMA Negeri 8 Pontianak. Metode yang digunakan dalam penelitian ini adalah metode kuantitatif deskriptif dengan pendekatan studi hubungan. Teknik analisis data yang digunakan adalah teknik analisis persentase, analisis rata-rata dan product moment. Hasil penelitian menunjukkan bahwa: (1) Rata-rata/mean motivasi belajar siswa kelas X SMA Negeri 8 Pontianak adalah 90,47 atau dalam kategori Sangat Baik. (2) Ratarata/mean hasil belajar siswa kelas X SMA Negeri 8 Pontianak adalah 79,88 atau dalam kategori Sangat Baik. (3) Terdapat hubungan positif dan signifikan motivasi belajar dengan hasil belajar Mata Pelajaran Sejarah Siswa Kelas X SMA Negeri 8 Pontianak. Hal ini ditunjukkan dari besarnya nilai $r$ hitung lebih besar dari $r$ tabel $(0,579>0,555)$ dan nilai signifikansi sebesar 0,000 , yang berarti kurang dari 0,05 $(0,000<0,05)$. Jadi dapat disimpulkan korelasi antara motivasi dan hasil belajar siswa dengan kategori sedang.
\end{abstract}

Kata Kunci: Motivasi, Hasil Belajar, Pelajaran Sejarah.

\begin{abstract}
This study aims to determine the Relationship Motivation with Learning Outcomes Subject History In Students Class X SMA Negeri 8 Pontianak. The method used in this research is descriptive quantitative method with relationship study approach. Data analysis techniques used are percentage analysis techniques, average analysis and product moment. The results showed that: (1) Mean of learning motivation of class X SMA Negeri 8 Pontianak is 90,47 or in very good category. (2) Mean of learning outcome of class X SMA Negeri 8 Pontianak student is 79,88 or in in very good category. (3) There is a positive and significant correlation between learning motivation and learning outcome in history subject grade X SMA Negeri 8 Pontianak. This is indicated by the magnitude of $r$ count greater than the $r$ table (0.579> 0.555) and the significance value of 0.000, which means less than 0.05 $(0,000<0.05)$. So it can be concluded the correlation between motivation and learning outcomes of student with medium category.
\end{abstract}

Keywords: Motivation, Learning Outcomes, History Lesson.

\section{PENDAHULUAN}

Pendidikan menjadi sesuatu yang sangat penting dalam kehidupan manusia baik secara filosofi maupun tidak. Di masa modern sekarang tampak secara jelas motif setiap manusia sebagai individu dalam mengenyam pendidikan tentulah berbeda-beda. Tapi terlepas dari perbedaan-perbedaan tujuan tersebut 
pendidikan pada dasarnya merupakan usaha sadar yang diciptakan manusia itu sendiri yang terencana untuk dapat mengembangkan potensi yang ada serta lebih berpikiran kritis dan inofatif. Selain itu juga menghasilkan keterampilan yang beraneka warna sehingga dapat bermanfaat bagi dirinya sendiri, bermasyarakat, dan bernegara.

Pendidikan dapat membina dan menyediakan lingkungan yang membantu peserta didik untuk dapat mengembangkan pengetahuan, memperbaiki akhlak dan meningkatkan keterampilannya secara optimal. SMA Negeri 8 Pontianak adalah salah satu lembaga pendidikan formal yang memiliki tugas dalam mengoptimalkan kualitas sumberdaya manusia. Berdasarkan hasil penelitian pendahuluan diketahui bahwa terdapat beberapa permasalahan terkait kualitas kemampuan peserta didik yaitu hasil belajar siswa.

Permasalahan yang muncul dalam proses pembelajaran diantaranya Pertama, siswa yang memiliki motivasi belajar yang tinggi akan lebih mudah dalam mencapai hasil belajar yang diinginkan namun yang terjadi masih banyak siswa yang belum memahami dan memiliki motivasi belajar yang tinggi. Hal itu terlihat dari masih ada siswa yang malas belajar, tidak konsentrasi dalam menerima pelajaran, kurang semangat dalam belajar, tidak berani bertanya dan mengemukakan pendapatnya dan hanya beberapa siswa yang mengerjakan tugas sementara yang lain ribut padahal motivasi belajar erat hubungannya dengan hasil belajar siswa.

Kedua, Belajar membutuhkan sarana dan prasarana misal buku, peralatan sekolah, fasilitas sekolah masih kurang dalam memenuhi kebutuhan siswa terhadap keberadaan fasilitas sekolah. Misal jumlah gedung, ruang praktik, perpustakaan dan lain-lain. Sehingga dapat disimpulkan bahwa kekurangan sarana belajar menghambat pencapaian hasil belajar.

Ketiga, Hasil belajar siswa masih rendah yaitu sesuai dengan nilai ulangan semester ganjil yang di peroleh siswa, masih banyak siswa yang memperoleh nilai di bawah KKM $<75$. Sedangkan Kriteria Ketuntasan Minimal (KKM) yang ditetapkan sekolah sesuai dengan kurikulum 2013 adalah >70. 
Berdasarkan kenyataan bahwa hasil belajar yang dicapai siswa masih belum memuaskan bagi semua pihak. Secara umum memberikan gambaran bahwa nilai rata-rata kelas yang masih relatif rendah sehingga perlu adanya usaha dan upaya baik siswa maupun guru kelas $\mathrm{X}$ untuk meningkatkan hasil belajar mereka untuk mencapai tujuan yang dikehendaki baik siswanya maupun lembaga pendidikan.

Menurut Slameto (2010: 3) "Belajar ialah suatu proses usaha yang dilakukan seseorang untuk memperoleh suatu perubahan tingkah laku yang baru secara keseluruhan, sebagai hasil pengalamannya sendiri dalam interaksi dengan lingkungannya". Sedangkan menurut Zuldafrial (2009:4-5) mengemukakan bahwa: "Belajar pada dasarnya adalah merupakan suatu proses mental karena orang yang belajar perlu memikirkan, menganalisa, mengingat dan mengambil kesimpulan dari apa yang dipelajari”. Berdasarkan penjelasan di atas mengenai pengertian belajar dapat disimpulkan bahwa belajar adalah semua kegiatan mental atau psikis yang dilakukan oleh seseorang sehingga menimbulkan perubahan tingkah laku yang berbeda antara sesudah belajar dan sebelum belajar.

Hasil dari proses pembelajaran kita kenal dengan hasil belajar. Pada suatu lembaga pendidikan, hasil belajar merupakan indikator yang penting untuk mengukur keberhasilan proses pembelajaran. Kegiatan belajar dan pembelajaran tidak terlepas dari hasil belajar yang akan dicapai. Menurut Sudjana (2009: 3) "mendefinisikan hasil belajar siswa pada hakikatnya adalah perubahan tingkah laku sebagai hasil belajar dalam pengertian yang lebih luas mencakup bidang kognitif, afektif dan psikomotor". Hal senada juga dikemukakan oleh Dimyati dan Mudjiono (2013: 3) "Hasil belajar merupakan hasil dari suatu interaksi tindak belajar dan tindak mengajar. Dari sisi guru, tindak mengajar diakhiri dengan proses evaluasi hasil belajar.Berdasarkan pengertian hasil belajar di atas, dapat penulis simpulkan bahwa hasil belajar adalah suatu hasil yang diperoleh siswa setelah siswa tersebut melakukan kegiatan belajar dan pembelajaran serta bukti keberhasilan yang telah dicapai oleh seseorang dengan melibatkan aspek kognitif, afektif maupun psikomotor, yang dinyatakan dalam symbol, huruf maupun kalimat. 
Penelitian ini menekankan motivasi belajar terhadap hasil belajar pada aspek kognitif, afektif dan psikomotor siswa. Motivasi belajar merupakan faktor pendukung yang dapat mengoptimalkan kecerdasan anak dan membawanya meraih prestasi. Menurut Luthans dalam Thoha (2007:207), motivasi terdiri dari tiga unsur, yakni kebutuhan (need), dorongan (drive) dan tujuan (goals). Selanjutnya menurut Djamarah (2008: 31), motivasi adalah suatu perubahan energi didalam peribadi seseorang yang ditandai dengan timbulnya efeltif (perasaan) dan reaksi untuk mencapai tujuan. Berdasarkan pendapat diatas dapat ditarik kesimpulan, bahwa motivasi adalah pikiran yang mendorong seseorang dalam melakukan kegiatan dalam berperilaku.

Motivasi, kadang-kadang istilah ini dipakai silih berganti dengan istilahistilah lainnya, seperti misalnya kebutuhan (need), keinginan (want), dorongan (drive), atau impuls. Sardiman, AM, (2014:75) menyatakan bahwa yang dimaksud dengan motivasi belajar adalah: Keseluruhan daya gerak di dalam diri siswa yang menimbulkan kegiatan belajar, yang menjamin kelangsungan dari kegiatan belajar dan yang memberikan arah pada kegiatan belajar, sehingga tujuan yang dikehendaki oleh subyek belajar itu tercapai. Dikatakan keseluruhan karena pada umumnya ada beberapa motif yang bersama-sama menggerakan siswa untuk belajar. Hasil belajar itu akan optimal kalau ada motivasi yang tepat.

Jadi motivasi belajar dapat untuk menggerakkan dan menumbuhkan motivasi siswa dalam menciptakan kondisi tertentu agar siswa merasa selalu butuh dan ingin terus belajar. Penerapan motivasi belajar kepada siswa merupakan salah satu upaya untuk meningkatkan hasil belajar siswa. Menurut Iskandar (2012: 181) "motivasi belajar adalah daya penggerak dari dalam diri individu untuk melakukan kegiatan belajar untuk menambah pengetahuan dan keterampilan serta pengalaman". Berdasarkan pendapat di atas, dapat disimpulkan bahwa motivasi adalah

Berdasarkan hal di atas maka tujuan dalam penelitian ini adalah untuk mengetahui hubungan motivasi dengan hasil belajar mata pelajaran sejarah pada siswa kelas X SMA Negeri 8 Pontianak . 


\section{METODE}

Penelitian ini menggunakan penelitian deskriptif kuantitatif dengan variabel bebas yakni motivasi belajar sedangkan variabel terikat dalam penelitian ini adalah hasil belajar Sejarah. Bentuk penelitian yang digunakan adalah studi hubungan atau korelasional yang bertujuan untuk mencari hubungan antara variabel bebas (motivasi belajar) dan variabel terikat (hasil belajar).

Populasi adalah wilayah generalisasi yang terdiri atas obyek atau subyek yang mempunyai kuantitas dan karakteristik tertentu yang ditetapkan oleh peneliti untuk dipelajari dan kemudian ditarik kesimpulannya (Sugiyono, 2013:55). Adapun populasi dalam penelitian ini adalah seluruh siswa kelas X IPS SMA Negeri 8 Pontianak dengan jumlah sebanyak 162 siswa. Setelah menetapkan populasi, maka langkah selanjutnya adalah menentukan sampel penelitian. Menurut Sugiyono (2013:91) menyatakan “ Sampel adalah bagian dari jumlah dan karakteristik yang dimiliki oleh populasi tersebut". Sampel yang digunakann dalam penelitian ini adalah berjumlah 113 siswa yang berdasarkan pada table Kretjei dalam Sugiyono (2013:98) dengan taraf kesalahan 5\% dengan kepercayaan $95 \%$ terhadap populasi. Adapun sebaran sampel dari masing-masing kelas, dengan rincian pada tabel 1 yakni:

Tabel 1. Distribusi Sampel Siswa Kelas X

\begin{tabular}{ccccc}
\hline \multirow{2}{*}{ No. } & \multirow{2}{*}{ Kelas } & \multicolumn{2}{c}{ Jenis Kelamin } & \multirow{2}{*}{ Jumlah } \\
\cline { 3 - 4 } & X MIS 1 & $\frac{20}{162} \times 113=14$ & $\frac{17}{162} \times 113=12$ & 26 \\
2 & X MIS 2 & $\frac{23}{162} \times 113=16$ & $\frac{19}{162} \times 113=13$ & 29 \\
3 & X MIS 3 & $\frac{26}{162} \times 113=18$ & $\frac{16}{162} \times 113=11$ & 29 \\
4 & X MIS 4 & $\frac{23}{162} \times 113=16$ & $\frac{18}{162} \times 113=13$ & 29 \\
\hline & Jumlah & $\mathbf{6 4}$ & $\mathbf{4 6}$ & $\mathbf{1 1 3}$
\end{tabular}

Sumber : TU SMA Negeri 8 Pontianak TA. 2017/2018

Dalam suatu penelitian diperlukan metode dan bentuk penelitian yang tepat serta teknik dan alat pengumpul data yang tepat karena ini merupakan faktor yang penting dalam penelitian. Dalam penelitian ini peneliti menggunakan teknik pengumpulan data yakni, teknik komunikasi tidak langsung berupa angket, teknik 
pengukuran berupa tes hasil belajar, dan teknik studi dokumenter berupa dokumen yang diperlukan.

Penelitian yang diteliti merupakan suatu penelitian kuantitatif, sehingga dalam menganalisis data dilakukan dengan menggunakan rumus statistik. Rumus analisis statistik data yang pertama menggunakan rumus perentase dengan mengacu pada tolak ukur kategori persentase berikut ini:

Tabel 2. Tolak Ukur Kategori Persentase

\begin{tabular}{cll}
\hline No & \multicolumn{1}{c}{ Persentase $(\%)$} & \multicolumn{1}{c}{ Kategori } \\
\hline 1 & $75,01-100$ & Sangat Baik \\
2 & $50,01-75,00$ & Baik \\
3 & $25,01-50,00$ & Cukup \\
4 & $00,00-25,00$ & Kurang \\
\hline
\end{tabular}

Selanjutnya untuk menjawab rumusan sub masalah yang kedua, yakni mengenai hasil belajar siswa menggunakan rumus rata-rata. Tahap yang terakhir adalah peneliti menggunakan rumus korelasi dengan teknik analisis product moment, tujuannya adalah untuk menguji hipotesis dalam penelitian apakah ada hubungan atau tidak antara variabe bebas dengan variabel tindakan. Untuk melihat kuat atau lemahnya hubungan antara kedua variabel tersebut, peneliti mengacu pada tabel $r$ hitung dengan $r$ tabel, sehingga hasil akhir dari penelitian ini dapat diketahui kuat atau lemah korelasi antara kedua variabel tersebut. Adapun $r$ tabel disajikan dalam tabel dibawah ini.

Tabel 3. Nilai Koefisien

\begin{tabular}{lll}
\hline No & Nilai Koefisien Korelasi & Interpretasi \\
\hline 1 & $0,00-0,199$ & Sangat rendah \\
2 & $0,20-0,399$ & Rendah \\
3 & $0,40-0,599$ & Sedang \\
4 & $0,60-0,799$ & Tinggi \\
5 & $0,80-1,00$ & Sangat Tinggi \\
\hline
\end{tabular}

Sumber : Sugiyono (2011: 143) 


\section{HASIL DAN PEMBAHASAN}

Data hasil penelitian terdiri dari variabel bebas yaitu variabel Motivasi Belajar(X) dan variabel terikat Hasil Belajar (Y). Pada bagian ini akan digambarkan atau dideskripsikan dari data masing-masing variabel yang telah diolah dilihat dari nilai rata rata (mean), median, modus, dan standar deviasi. Berikut ini rincian hasil pengolahan data yang telah dilakukan dengan bantuan SPSS versi 16.0.

a. Variabel Motivasi Belajar

Data variabel Motivasi Belajar diperoleh melalui angket yang terdiri dari 25 item dengan jumlah responden 113 siswa. Ada 5 alternatif jawaban dimana skor tertinggi 5 dan skor terendah 1. Berdasarkan data variabel Motivasi Belajar, diperoleh skor tertinggi sebesar 109 dan skor terendah sebesar 69. Hasil analisis harga Mean (M) sebesar 90,47, Median (Me) sebesar 90,00, Modus (Mo) sebesar 93,00 dan Standar Deviasi (SD) sebesar 8,023. Berdasarkan nilai Mean dari hasil analisis data, maka dapat disimpulkan motivasi belajar siswa SMA Negeri 8 Pontianak dalam katagori Sangat Baik.

b. Variabel Hasil Belajar

Data variabel Hasil Belajar diperoleh melalui rata-rata nilai ulangan harian dari mata pelajaran Sejarah dengan jumlah responden 113 siswa. Ada 5 alternatif jawaban dimana skor tertinggi 1 dan skor terendah 0. Berdasarkan data variabel Hasil Belajar, diperoleh skor tertinggi sebesar 90 dan skor terendah sebesar 67. Hasil analisis harga Mean (M) sebesar 79,88, Median (Me) sebesar 80,00, Modus (Mo) sebesar 77 dan Standar Deviasi (SD) sebesar 5,850. Berdasarkan nilai Mean dari hasil analisis data, maka dapat disimpulkan hasil belajar siswa SMA Negeri 8 Pontianak dalam katagori Sangat Baik.

Langkah selanjutnya dalam penelitian ini adalah menentukan nilai normalitas, linieritas, dan pengujian hipotesis. Uji Normalitas pada penelitian ini dilakukan untuk mengetahui apakah semua variabel penelitian berdistribusi normal atau tidak. Normalitas diujikan pada masing-masing variabel penelitian yang meliputi: Motivasi Belajar dan Hasil Belajar Siswa. Pengujian normalitas menggunakan teknik analisis Kolmogorov-Smirnov dan untuk perhitungannya 
menggunakan program SPSS 16.0 for Windows. Hasil normalitas untuk masingmasing variabel penelitian disajikan berikut ini:

\section{Tabel 4. Hasil Normalitas}

NPar Tests

Descriptive Statistics

\begin{tabular}{lcclll}
\hline & N & Mean & Std. Deviation & \multicolumn{2}{l}{ Minimum } \\
\hline Motivasi_Belajar & 113 & 90.47 & 8.023 & 69 & 109 \\
Hasil_Belajar & 113 & 79.88 & 5.850 & 67 & 90 \\
\hline
\end{tabular}

One-Sample Kolmogorov-Smirnov Test

\begin{tabular}{|c|c|c|c|}
\hline & & Motivasi_Belajar & Hasil_Belajar \\
\hline \multicolumn{2}{|l|}{$\mathrm{N}$} & 113 & 113 \\
\hline \multirow{2}{*}{ Normal Parameters ${ }^{a}$} & Mean & 90.47 & 79.88 \\
\hline & Std. Deviation & 8.023 & 5.850 \\
\hline \multirow{3}{*}{ Most Extreme Differences } & Absolute & .062 & .116 \\
\hline & Positive & .049 & .105 \\
\hline & Negative & -.062 & -.116 \\
\hline \multicolumn{2}{|c|}{ Kolmogorov-Smirnov Z } & .658 & 1.236 \\
\hline \multicolumn{2}{|c|}{ Asymp. Sig. (2-tailed) } & .780 & .094 \\
\hline
\end{tabular}

Hasil normalitas menunjukkan bahwa semua variabel penelitian mempunyai nilai signifikansi lebih besar dari 0,05 pada (sig>0,05), sehingga dapat disimpulkan bahwa data penelitian berdistribusi normal. Langkah selanjutny adalah menentukan nilai linieritas. Tujuan linieritas adalah untuk mengetahui apakah variabel bebas dan variabel terikat mempunyai pengaruh yang linier apa tidak. Kriteria pengujian linieritas adalah jika nilai $F_{\text {hitung }}$ lebih kecil dari $F_{\text {tabel }}$ pada nilai taraf signifikansi 0,05 , maka hubungan antara variabel bebas terhadap varibel terikat adalah linier. Berdasarkan hasil olah data, maka hasil nilai linieritas menunjukkan bahwa taraf signifikansi sebesar 0,273>0,05; sehingga kedua variabel tersebut dapat dikatakan linier.

Langkah selanjutnya adalah pengujian hipotesis, Hipotesis dalam penelitian ini adalah "Terdapat hubungan positif dan signifikan motivasi belajar dengan hasil belajar Mata Pelajaran Sejarah Kelas X SMA Negeri 8 Pontianak”. 
Dasar pengambilan keputusan menggunakan koefisien korelasi (r ). Jika koefisien korelasi bernilai positif maka dapat dilihat adanya hubungan yang positif antara variabel bebas dan variabel terikat. Sedangkan untuk menguji signifikansi adalah dengan membandingkan nilai $r_{\text {hitung }}$ dengan $r_{\text {tabel }}$ pada taraf signifikansi 5\%. Jika nilai $r_{\text {hitung }}$ lebih besar dari nilai $r_{\text {tabel }}$ maka hubungan tersebut signifikan. Sebaliknya jika nilai $r_{\text {hitung }}$ lebih kecil dari $r_{\text {tabel }}$ maka hubungan tersebut tidak signifikan. Untuk menguji hipotesis tersebut maka digunakan analisis korelasi Product Moment dari Karl Person. Adapun hasil korelasi Product Moment dari Karl Person (X2-Y) menggunakan aplikasi SPSS versi 16 adalah sebagai berikut:

Tabel 5. Ringkasan Hasil korelasi Product Moment dari Karl Person (X2-Y) Correlations

\section{Correlations}

\begin{tabular}{llll}
\hline & & Motivasi_Belajar & Hasil_Belajar \\
\hline Motivasi_Belajar & Pearson Correlation & 1 & $.579^{* *}$ \\
& Sig. (2-tailed) & & .000 \\
& $\mathrm{~N}$ & 113 & 113 \\
\hline Hasil_Belajar & Pearson Correlation & $.579^{* *}$ & 1 \\
& Sig. (2-tailed) & .000 & \\
& $\mathrm{~N}$ & 113 & 113 \\
\hline
\end{tabular}

**. Correlation is significant at the 0.01 level (2-tailed).

Berdasarkan tabel di atas, maka dapat diketahui bahwa nilai $\mathrm{r}$ hitung lebih besar dari $r$ tabel $(0,579>0,555)$ dan nilai signifikansi sebesar 0,000 , yang berarti kurang dari $0,05(0,000<0,05)$. Berdasarkan hasil tersebut, maka hipotesis pertama dalam penelitian ini tidak ditolak. Hasil analisis korelasi product moment menunjukkan Terdapat hubungan positif dan signifikan motivasi belajar dengan hasil belajar Mata Pelajaran Sejarah Kelas X SMA Negeri 8 Pontianak.

Penelitian ini bertujuan untuk menguji hubungan motivasi belajar dengan hasil belajar Mata Pelajaran Sejarah Kelas X SMA Negeri 8 Pontianak. Berdasarkan hasil analisis dengan korelasi product moment menunjukkan terdapat hubungan positif dan signifikan motivasi belajar dengan hasil belajar Mata Pelajaran Sejarah Kelas X SMA Negeri 8 Pontianak. Hal ini ditunjukkan dari 
besarnya nilai $r$ hitung lebih besar dari $r$ tabel $(0,579>0,555)$ dan nilai signifikansi sebesar 0,000, yang berarti kurang dari 0,05 $(0,000<0,05)$.; sehingga penelitian ini berhasil membuktikan hipotesis yang menyatakan bahwa "Terdapat hubungan positif dan signifikan motivasi belajar dengan hasil belajar Mata Pelajaran Sejarah Kelas X SMA Negeri 8 Pontianak".

Dalam proses belajar mengajar, keberhasilan dan kegagalan tidak dapat dilihat dari satu faktor saja tetapi perlu memandang dari berbagai segi atau faktor yang mempengaruhi. Salah satu faktor yang berasal dari dalam siswa adalah motivasi belajar. Motivasi untuk belajar adalah kondisi psikologis yang mendorong siswa untuk belajar. Penemuan-penemuan penelitian menunjukkan bahwa hasil belajar pada umumya meningkat jika motivasi untuk belajar bertambah. Banyak bakat anak tidak berkembang karena tidak diperolehnya motivasi yang tepat. Jika seseorang mendapat motivasi yang tepat, maka lepaslah tenaga yang luar biasa, sehingga tercapai hasil-hasil yang semula tidak terduga.

Motivasi belajar siswa merupakan daya penggerak dalam diri siswa untuk dapat mencapai hasil belajar siswa yang optimal, sehingga tujuan yang dikehendaki subjek belajar itu dapat tercapai. Motivasi itu dapat berasal dari diri pribadi siswa itu sendiri (motivasi intrinsik) dan berasal dari luar diri pribadi siswa (ekstrinsik). Siswa yang mempunyai motivasi tinggi akan melaksanakan kegiatan belajarnya dengan penuh keyakinan dan tanggung jawab bila dibandingkan dengan siswa yang memiliki motivasi belajar rendah, sehingga akan mencapai hasil belajar yang optimal.

Motivasi belajar yang tinggi tercemin dari ketekunan yang tidak mudah patah untuk mencapai sukses meskipun dihadang oleh berbagai kesulitan. Motivasi yang tinggi dapat menggiatkan aktivitas belajar siswa. Siswa yang mempunyai motivasi tinggi akan melaksanakan kegiatan belajarnya dengan penuh keyakinan dan tanggung jawab bila dibandingkan dengan siswa yang memiliki motivasi belajar rendah, sehingga akan mencapai hasil belajar yang optimal. Dengan demikian dapat disimpulkan bahwa siswa yang memiliki motivasi belajar tinggi mempunyai peluang lebih besar untuk memperoleh prestasi belajar yang lebih baik dibandingkan siswa yang memiliki motivasi belajar rendah. 


\section{SIMPULAN}

Berdasarkan hasil penelitian dan pembahasan, maka dapat ditarik beberapa kesimpulan sebagai berikut. (1) Rata-rata/mean motivasi belajar siswa kelas X SMA Negeri 8 Pontianak adalah 90,47 atau dalam kategori Sangat Baik. (2) Rata-rata/mean hasil belajar siswa kelas X SMA Negeri 8 Pontianak adalah 79,88 atau dalam kategori Sangat Baik. (3) Terdapat hubungan positif dan signifikan motivasi belajar dengan hasil belajar Mata Pelajaran Sejarah Siswa Kelas X SMA Negeri 8 Pontianak. Hal ini ditunjukkan dari besarnya nilai $r$ hitung lebih besar dari $r$ tabel $(0,579>0,555)$ dan nilai signifikansi sebesar 0,000 , yang berarti kurang dari $0,05(0,000<0,05)$. Jadi dapt disimpulkan korelasi antara motivasi dan hasil belajar siswa dengan kategori sedang.

\section{DAFTAR PUSTAKA}

Djamrah, S.B. 2008. Psikologi Belajar, Edisi 2. Jakarta: Rineka Cipta.

Iskandar, Agung. 2012. Panduan Penelitian Tindakan Kelas bagi Guru. Jakarta : Bestari Buana Murni.

Mudjiono \& Dimyati. 2013. Belajar dan Pembelajaran. Jakarta: Rineka Cipta.

Sardiman. (2014). Interaksi dan Motivasi Belajar Mengajar. Jakarta: Raja Grafindo Persada.

Slameto. (2010). Belajar dan Faktor-faktor yang mempengaruhinya. Jakarta: Bumi Aksara.

Sudjana, Nana. (2009). Penilaian Hasil Proses Belajar Mengajar. Bandung: PT Ramaja Rosdakarya.

Sugiyono .2013. Metode Penelitian Kuantitatif Kualitatif dan $R \&$ D. Bandung : Alfabeta.

Thoha, Miftah. 2007. Kepemimpinan Dalam Manajemen. Jakarta: PT. Raja. Grafindo Persada.

Zuldafrial. (2009). Belajar Interaksi Belajar Mengajar”. Pontianak: STAIN Press Pontianak. 